\title{
Geographical distribution and virulence phenotypes of Puccinia striiformis f. sp. tritici from wheat in Yunnan, China
}

\author{
Mohamed A. Gad ${ }^{\mathrm{a}, \mathrm{b}}$, Haoxing Li ${ }^{\mathrm{c}}$, Md. Ashraful Alam ${ }^{\mathrm{a}, \mathrm{d}}$, Muhammad Sajjad ${ }^{\mathrm{e}, *}$, Mingju Li ${ }^{\mathrm{a}, *}$ \\ a Institute of Agricultural Environment and Resources, Yunnan Academy of Agricultural Sciences, \\ Kunming 650205 China \\ b Wheat Diseases Research Department, Plant Pathology Research Institute, Agricultural Research Center, \\ Giza 12619 Egypt \\ c College of Life Science and Technology, Huazhong Agricultural University, Wuhan 430070 China \\ d Bangladesh Wheat and Maize Research Institute, Dinajpur 5200 Bangladesh \\ e Department of Biosciences, COMSATS University Islamabad, Islamabad 45550 Pakistan
}

*Corresponding authors, e-mail: muhammad.sajjad@comsats.edu.pk, lily69618@163.com

Received 25 May 2019

Accepted 11 Nov 2019

\begin{abstract}
Wheat stripe rust, caused by Puccinia striiformis is a widespread and destructive disease of wheat, causing significant losses in yield and quality. Survey of wheat stripe rust samples and identification of physiological races using $Y r$ single-gene differential lines are very important in describing virulence pattern variation and geographical distribution of rust pathotypes. In the present study, a total of 86 races characterized from 125 stripe rust isolates were collected from Yunnan and Sichuan provinces of China during the 2017/2018 wheat growing season. The races v1 and v2 were widely distributed with virulence frequency of 8.8 and $8 \%$, respectively. The remaining races have a lower frequency $\leqslant 3 \%$. The 86 races clustered into two major virulence clusters: cluster-I comprised two races v29 and v30 and had relatively narrow virulence spectra, while cluster-II involved other 84 races and had broad virulence spectra. High virulence frequencies of Pst population (>73\%) were detected for $\operatorname{Yr1}$, Yr2, $Y r 6, \operatorname{Yr} 7, \operatorname{Yr} 8, \operatorname{Yr} 9, \operatorname{Yr} 11$, Yr(17,29), Yr17, Yr18, Yr25, Yr26, Yr30, Yr32, YrA, YrSK, YrSP, YrSu, Yr(8,19), Yr(7,25), and $\operatorname{Yr}(10, M o r)$ genes. Moderate virulence frequencies of Pst population (16-73\%) were observed for $Y r 3, \operatorname{Yr} 27, \operatorname{Yr}(2, H V I I)$, and $\operatorname{Yr}(7,22,23)$ genes. No isolate was detected to be virulent to $\operatorname{Yr} 5$ and $\operatorname{Yr} 10$ genes. The four genes $\operatorname{Yr} 5, \operatorname{Yr} 10, \operatorname{Yr} 15$, and $\operatorname{Yr} 24$ were regarded as effective genes. Therefore, monitoring distribution and frequency changes of virulence toward the $Y r$ genes is important for cultivar selection with adequate resistance for growing in specific geographic regions and for developing new cultivars with durable and a high-level resistance.
\end{abstract}

KEYWORDS: wheat, Puccinia striiformis, stripe rust, virulence, resistance gene

\section{INTRODUCTION}

Wheat stripe rust (yellow rust) caused by Puccinia striiformis $\mathrm{f}$. sp. tritici (Pst) is the most destructive disease worldwide ${ }^{1,2}$. China is the largest epidemic zone, where about 400 million hectares of the wheat crop is infected by the disease every year since the 1950s. Five significant booms and busts of stripe rust occurred in China ${ }^{3}$. The first outbreak of yellow rust disease occurred in 1950, breaking down resistance of $Y r 1$ gene in wheat variety Bima ${ }^{4}$. The second outbreak was in 1964, while the third was in 1987 due to the emergence of new race (CYR29) virulent to $\mathrm{Yr} 9$ gene, located in chromosome 1BL. The fourth major epidemic broke out in 2002 due to the appearance of CYR32 race virulent to Yr4 gene present in wheat variety Fan $-6^{5}$. The fifth change and current cycle of outbreaks occurred in 2008 due to break-down of resistance of $Y r 24$ and $Y r 26$ genes in wheat variety Guinong 22 by the stripe rust race $\mathrm{V} 26^{6}$.

Yunnan is located in Southwest China, neighboring the Himalayas, in which geography is complex, and altitude is quite different, which leads to a diverse climate and ecosystem. Therefore, wheat stripe rust occurs quickly; the pathogen constantly mutates, which results in complicated virulence and higher genetic diversity of pathogens ${ }^{7}$. The outbreak of wheat stripe rust in Yunnan causes not only economic yield losses, but also provide original incursion sources for other parts of China ${ }^{8}$, which 
plays a crucial role in large scale disease epidemics. Previous research indicated that the Himalayas and neighboring regions such as Pakistan, Nepal, as well as China, are the center of origin for wheat stripe rust pathogen ${ }^{9}$. Thus, Yunnan is a vital ring for the migration chain of wheat stripe rust pathogen in the world, or it may be one of the wheat stripe rust origins. Therefore, study on the population virulence of the pathogen and effectiveness of resistance genes will provide useful information for breeding and rational use of resistant genes; in the meantime, it will monitor new races and give evidence for the origin and migration of the pathogen.

Physiological races determined by infection type (IT) of isolates on a set of differentials, which include selective host genotype or monogenic lines. Due to differences among regions, the pathogen population structure, study level, as well as historical reasons, different countries, and areas use respective different nomenclature to characterize race and virulence in the world. International and European set combined as a set of differentials used in Europe, Australia, the Middle East, South Africa, and Nepal, of which binary system nomenclature is used. North American differentials employed in America and Canada use chronological terminology $^{10}$ and named up to V220 by 2016, including 18 single gene lines ${ }^{11}$.

Chinese differentials are a half-opened system, include 19 cultivars, use chronological nomenclature $^{12}$, and by now named up to CYR34. By 2014, 303 races had been identified in the whole of China (National Initiative of Wheat Rust Annual Report, 2015). For naming races, various systems have been used to designate races of the rust pathogens. The number system, which names races with numbers and usually in sequential order, is the oldest and still widely used. Races of $P$. striiformis $\mathrm{f}$. sp. tritici in China, India, and the United States have been named using numbers ${ }^{6,13-15}$.

Except North American differentials, the other differentials are not a set of near-isogenic lines (NILs) and contain one gene, multi-genes or unknown genes ${ }^{10}$. The results of races by these differentials cannot reflect the information of resistant genes directly, although they provide some useful information for the wheat production. Also, with the mutation of stripe rust pathogen virulence in China, current Chinese differentials cannot characterize many isolates in recent years, especially for Yunnan isolates, which needs to be adjusted to adapt the situation. Wan ${ }^{10}$ suggested to use a NILs set as differentials, this can monitor the effectiveness of resistant genes directly, and provide direct information for wheat production. Wellings et $\mathrm{al}^{16}$ developed NILs to monitor virulence in the P. striiformis f. sp. tritici populations throughout the world.

Genetic control of wheat stripe rust is achieved by over 50 formally named Yellow rust $(\mathrm{Yr})$ resistance $(R)$ genes identified by the continuous efforts of plant breeders and pathologists over the last 100 years ${ }^{17}$. Historically, pathologists have focused on the isolation of Pst from wheat fields and have determined the ability of these isolates to infect a defined set of wheat lines carrying different $\mathrm{Yr} \mathrm{R}$ genes. The resulting infection phenotypes determine the virulence profiles and pathogen race nomenclature of the Pst isolates, enabling a comparison between spatially and temporally distinct collection events ${ }^{18}$. In the last 10 years, modern DNA-based tools have expanded our ability to study this fungus, and this has led to the cloning of the first $Y r$ R genes, the identification of the full life cycle of Pst, it's center of genetic diversity and past global migration patterns, and the provision of draft Pst genomes.

Control via $\mathrm{Yr} \mathrm{R}$ genes is the most economical and preferred containment strategy for wheat stripe rust. $\mathrm{R}$ genes in wheat are historically divided into two phenotypically, mechanistically, and genetically distinct categories. Seedling resistance genes are characterized by a strong to moderate immune response that fully curtails fungal infection and sporulation at all developmental stages. While, adult plant resistance is seen as more durable because, in the asexual stage of Pst, a single genetic variation appears insufficient to overcome this type of resistance ${ }^{19}$. Novel genetically diverse Pst incursions, however, can reduce the effectiveness of adult plant resistance ${ }^{20}$. $\mathrm{Yr}$ genes provide useful information for identifying races and race groups for monitoring virulence changes. In this study, we use $29-Y r$ gene differential lines to study race and virulence of Pst population of Yunnan and Sichuan provinces in China, to provide information for wheat production.

\section{MATERIALS AND METHODS}

\section{Disease surveys}

Wheat fields and disease nurseries (rust trap nurseries) were surveyed during 2017/2018 growing season to monitor the occurrence, development, and distribution of stripe rust in 11 counties of Yunnan and another county of Sichuan in China including Chuxiong (CX), Dali (DL), Honghe (HH), Kunming (KM), Lincang (LC), Lijiang (LJ), Nujiang 
(NJ), Qujing (QJ), Wenshan (WS), Yuxi (YX), Zhaotong (ZT), Sichuan (SC).

\section{Sample collections}

Stripe rust samples were collected from more than 100 wheat cultivars. From monitoring nurseries, each wheat cultivar considered as a sampling site, and from the field, each sampling site was at least $1000 \mathrm{~m}$ apart. Three to five naturally infected wheat leaves were collected from each place, and each leaf was wrapped in bibulous paper. Wheat samples were taken from different regions, different altitudes, and various cultivars to make them truly representative.

\section{Urediniospores production}

Leaf samples of wheat were incubated on watersoaked tissue paper in Petri dishes in the dark at $20^{\circ} \mathrm{C}$ for $5-6 \mathrm{~h}$ to produce fresh urediniospores, which were used to inoculate seedlings of the highly susceptible wheat cultivar Mingxian 169 to increase the urediniospores. Seven days after sowing, seedlings with the first leaf expanded completely inoculated with urediniospores from infected leaf samples. Inoculated plants were incubated in a dew chamber at $10^{\circ} \mathrm{C}$ for $24 \mathrm{~h}$ without light and then kept in a growth chamber with temperature $11^{\circ} \mathrm{C}$ $17^{\circ} \mathrm{C}$ with $16 \mathrm{~h}$ of light. Plants inoculated with urediniospores from individual samples were separated using a booth to avoid contamination. Fresh urediniospores produced on inoculated seedlings leaves were then collected till approximately $50 \mathrm{mg}$ for each isolate and temporarily stored in desiccators kept at $4^{\circ} \mathrm{C}$.

\section{Race Identification}

A set of $29-Y r$ genes differential lines was used to determine races of Pst (Table 1). Five to seven seeds of each differential planted in a plastic box. Seedlings were inoculated at the two-leaf stage with urediniospores of each isolate after mixing with talcum powder at a ratio of approximately 1:20. 14 to 16 days after inoculation, infection types (IT) on differential lines were recorded using the 0-4 scale, i.e., $0=$ no visible symptoms, 0 ; = necrotic flecks, $1=$ necrotic and chlorotic areas with restricted sporulation, $2=$ small to medium uredia with chlorosis and necrosis, $3=$ mediumsized uredia with chlorosis, and $4=$ abundant sporulation without chlorosis ${ }^{21}$. In the scale, $0-2=$ resistant lines (avirulent) while 3-4 = susceptible lines (virulent) ${ }^{22}$.
Table 1 Set of wheat differential lines and their $Y r$ genes used for resistance to $P$. striiformis $\mathrm{f}$. $\mathrm{sp}$. tritici.

\begin{tabular}{|c|c|}
\hline Differential line & R gene $/ Y r$ gene $(s)$ \\
\hline Avocet $S^{*} / Y r 1$ & $\operatorname{Yr} 1$ \\
\hline Kalyansona & $\operatorname{Yr} 2$ \\
\hline Danish 1 & $\operatorname{Yr} 3$ \\
\hline T. spelta album & $\operatorname{Yr} 5$ \\
\hline Avocet $S * 6 / Y r 6$ & Yr6 \\
\hline Avocet $S * 6 /$ Lee & $\operatorname{Yr} 7$ \\
\hline Avocet $S * 6 /$ Compair & $\operatorname{Yr} 8$ \\
\hline Avocet $S * 6 / Y r 9$ & $Y r 9$ \\
\hline Avocet $S * 6 / \operatorname{Yr} 10$ & $\operatorname{Yr} 10$ \\
\hline Avocet $S * 3 /$ Joss Cambier & $\operatorname{Yr} 11$ \\
\hline Avocet $S * 6 / T$. dicoccoides & $\operatorname{Yr} 15$ \\
\hline Pavon 76 & $\operatorname{Yr}(17,29)$ \\
\hline Avocet $S * 6 / Y r 17$ & Yr17 \\
\hline Avocet $S * 6 / Y r 18$ & $\operatorname{Yr} 18$ \\
\hline Avocet S*6/Yr24 & Yr24 \\
\hline Hugenoot & $\operatorname{Yr} 25$ \\
\hline Avocet $S * 6 / Y r 26$ & $\operatorname{Yr} 26$ \\
\hline Avocet $S * 6 / Y r 27$ & Yr27 \\
\hline Parula & Yr30 \\
\hline Avocet $S * 6 / Y r 32$ & Yr32 \\
\hline Avocet R & $Y r A$ \\
\hline Avocet $S * 3 /$ Opata 85 & $\operatorname{YrSK}$ \\
\hline Avocet $S * 6 / Y r S P$ & YrSP \\
\hline Suwon 92/Omar & YrSu \\
\hline Compare & $\operatorname{Yr}(8,19)$ \\
\hline Reichersberg 42 & $\operatorname{Yr}(7,25)$ \\
\hline Heiens VII & $\operatorname{Yr}(2, H V I I)$ \\
\hline Moro & $\operatorname{Yr}(10, M o r)$ \\
\hline Lee & $\operatorname{Yr}(7,22,23)$ \\
\hline
\end{tabular}

\section{Determination of virulence frequency percentage}

The percentage of virulence frequency for each of designated races in the survey was calculated as the number of virulent isolates to the total number of tested isolates, according to this equation ${ }^{23}$ :

$$
\text { Virulence frequency }(\%)=\frac{\text { No. virulence }}{\text { No. isolates }} \times 100
$$

Virulence frequencies were classified as high $(>73 \%)$, moderate $(16-73 \%)$, and low $(<10 \%)$. The distributions of the detected races were summarized by locations.

\section{Cluster analysis and coefficients of correlations}

A similarity matrix of virulence phenotypes based on simple matching coefficient was used to construct a dendrogram using the unweighted pair group method with arithmetic means (UPGMA) clustering method in numerical taxonomy system (NTSYSpc 
version 2.2 ${ }^{24}$. The corresponding $\varphi$ coefficient of association between virulence to the 29-Yr-gene differentials (formula 17.5) ${ }^{25}$ was calculated using the NTSYSpc package, version 2.2 , and based on the virulence-avirulence patterns of the 125 isolates. For each of tested $\mathrm{Yr}$ genes, virulence coded as one and avirulence as $0^{26,27}$.

\section{RESULTS}

\section{Race frequency and distribution}

Eighty-six races were characterized from 125 isolates collected from Yunnan and Sichuan provinces in China based on their virulence/avirulence patterns to the 29 wheat differential genotypes. The frequencies of races ranged from $0.8 \%$ (only one isolate) to $8.8 \%$ (v1). Two dominant races were $8.8 \%$ (v1), and $8 \%$ (v2) while 4 races were $2.4 \%$ (v3, v4, v5, and v6); other 80 races had frequencies below $2 \%$. Races v1 and v2 were the most widely distributed races and were detected in 5 counties while v3 and v6 were distributed in 3 counties; the remaining races were only distributed in less than three counties.

Different numbers of races were detected in different locations. The number of races ranged from 1 in the Nujiang to 16 and 15 in Lincang and Yuxi, respectively. The site of Lincang, Yuxi, Chuxiong, and Sichuan had relatively high numbers of races compared to other counties, with more than 10 races. The percentage of virulence races for each county was listed in Table 2.

Table 2 Virulence races of Puccinia striiformis in different locations.

\begin{tabular}{|c|c|c|c|}
\hline County & $\begin{array}{l}\text { No. of } \\
\text { races }\end{array}$ & Pst race & $\begin{array}{c}\text { Race } \\
\%\end{array}$ \\
\hline Lincang & 16 & $\begin{array}{l}\text { v1, v2, v6, v7, v11, v15, v16, v17, } \\
\text { v21, v27, v28, v34, v35, v48, v72, } \\
\text { v75 }\end{array}$ & 18.60 \\
\hline Yuxi & 15 & $\begin{array}{l}\text { v1, v2, v9, v12, v13, v15, v26, } \\
\text { v52, v53, v65, v66, v67, v69, v85, } \\
\text { v86 }\end{array}$ & 17.44 \\
\hline Chuxiong & 14 & $\begin{array}{l}\text { v6, v25, v29, v36, v38, v54, v56, } \\
\text { v58, v59, v64, v68, v76, v77, v82 }\end{array}$ & 16.28 \\
\hline Sichuan & 13 & $\begin{array}{l}\text { v3, v4, v5, v7, v14, v17, v22, v41, } \\
\text { v47, v60, v61, v70, v74 }\end{array}$ & 15.12 \\
\hline Qujing & 10 & $\begin{array}{l}\text { v1, v2, v4, v8, v18, v20, v23, v50, } \\
\text { v51, v81 }\end{array}$ & 11.63 \\
\hline Wenshan & 9 & $\begin{array}{l}\text { v1, v2, v18, v30, v39, v43, v55, } \\
\text { v62, v71 }\end{array}$ & 10.46 \\
\hline Kunming & 8 & v1, v3, v6, v9, v10, v11, v42, v44 & 9.30 \\
\hline Dali & 7 & v19, v46, v73, v78, v79, v80, v84 & 8.14 \\
\hline Lijiang & 7 & v24, v31, v32, v33, v37, v40, v45 & 8.14 \\
\hline Honghe & 4 & v14, v49, v57, v63 & 4.65 \\
\hline Zhaotong & 2 & v3, v83 & 2.33 \\
\hline Nujiang & 1 & v2 & 1.16 \\
\hline
\end{tabular}

\section{Cluster analysis}

A dendrogram constructed using the NTSYSpc 2.2 software divided the races into two clades. ClusterI comprises two races v29 and v30. Cluster-II comprises 84 races (Fig. 1). The two races of ClusterI had relatively narrow virulence spectra. The v29 was virulent to 6 , and v30 was virulent to 7 of the 29 -Yr gene differentials. Cluster-II had 84 races that had wide virulence spectra, ranging from 8 (v84) to 24 (v3, v7, v11, and v60) virulence. The ClusterII separated into two sub-clusters. Sub-cluster-1 comprised only one race (v84) and had narrow virulence spectra with Cluster-I. Sub-cluster-2 had wide virulence spectra ranging from 12 (v37) to 24 (v3, v7, v11, and v60) virulence (Table S1).

\section{Virulence frequencies for $\mathrm{Yr}$ genes and their distributions}

The virulence frequencies for $Y r 1, Y r 2, Y r 6, Y r 7$, Yr8, Yr9, Yr11, Yr17, Yr18, Yr25, Yr26, Yr30, Yr32, YrA, YrSK, YrSP, YrSu, $\operatorname{Yr}(8,19), \operatorname{Yr}(7,25)$, $\operatorname{Yr}(10, M o r)$ and $\operatorname{Yr}(17,29)$ genes were high, ranging from $73.6-98.4 \%$, and this virulence was detected in all counties of Yunnan and Sichuan provinces (Table 3). No isolates virulent to $\mathrm{Yr} 5$ and $\mathrm{Yr} 10$ were detected, indicating that these two genes were still effective against all races identified so far in Yunnan and Sichuan provinces of China. Moderate frequency $(16.8-47.2 \%)$ of virulence was detected for $Y r 3, \operatorname{Yr} 27, \operatorname{Yr}(2, H V I I)$, and $\operatorname{Yr}(7,22,23)$ genes. The virulence frequencies to $\mathrm{Yr} 15$ and $\mathrm{Yr} 24$ were low $(0.8 \%$ and $1.6 \%$, respectively). Virulence to Yr15 was detected only in the Sichuan province. Similarly, virulence to $\mathrm{Yr} 24$ was identified only in Chuxiong county of Yunnan province (Table 3). All races were virulent to $\mathrm{Yr} 2$ except v83 and v84, and to $\operatorname{Yr}(17,29)$ except v30 and v77.

\section{$\varphi$ Coefficient of correlation}

The coefficient of correlation between virulence to the 29-Yr-gene differentials was calculated based on the virulence-avirulence patterns of the 125 isolates. A highly positive correlation $(>0.50)$ was identified between virulence to $\operatorname{YrSP}$ and $\operatorname{Yr}(8,19)$ or $\operatorname{Yr} 17$; $\operatorname{Yr}(10, M o r)$ and $\operatorname{Yr} 17, \operatorname{Yr}(8,19)$ or $\operatorname{YrSP}$ (Fig. 2), indicated with yellow color. Negative correlation $(<0)$ was found between virulence to $\operatorname{Yr} 1$ or $\mathrm{Yr} 2$ and $Y r 3, \operatorname{Yr}(17,29), Y r 17, \operatorname{Yr} 18$ or $Y r 25$; $Y r 1$ and $Y r 2$, Yr7, Yr11, Yr32, YrA, YrSK, $Y r(7,25)$ or $\operatorname{Yr}(7,22,23)$; $Y r 3$ and $Y r 6, Y r 15, Y r 24$ or $\operatorname{Yr}(2, H V I I) ; Y r 6$ or $\operatorname{Yr} 7$ and $\operatorname{YrSP}, \operatorname{Yr}(8,19), \operatorname{Yr}(2, H V I I), \operatorname{Yr}(10, M o r)$ or $\operatorname{Yr}(7,22,23) ; \operatorname{Yr} 7$ and $\operatorname{Yr} 8, \operatorname{Yr} 25, \operatorname{YrSP}, \operatorname{Yr}(8,19)$, 


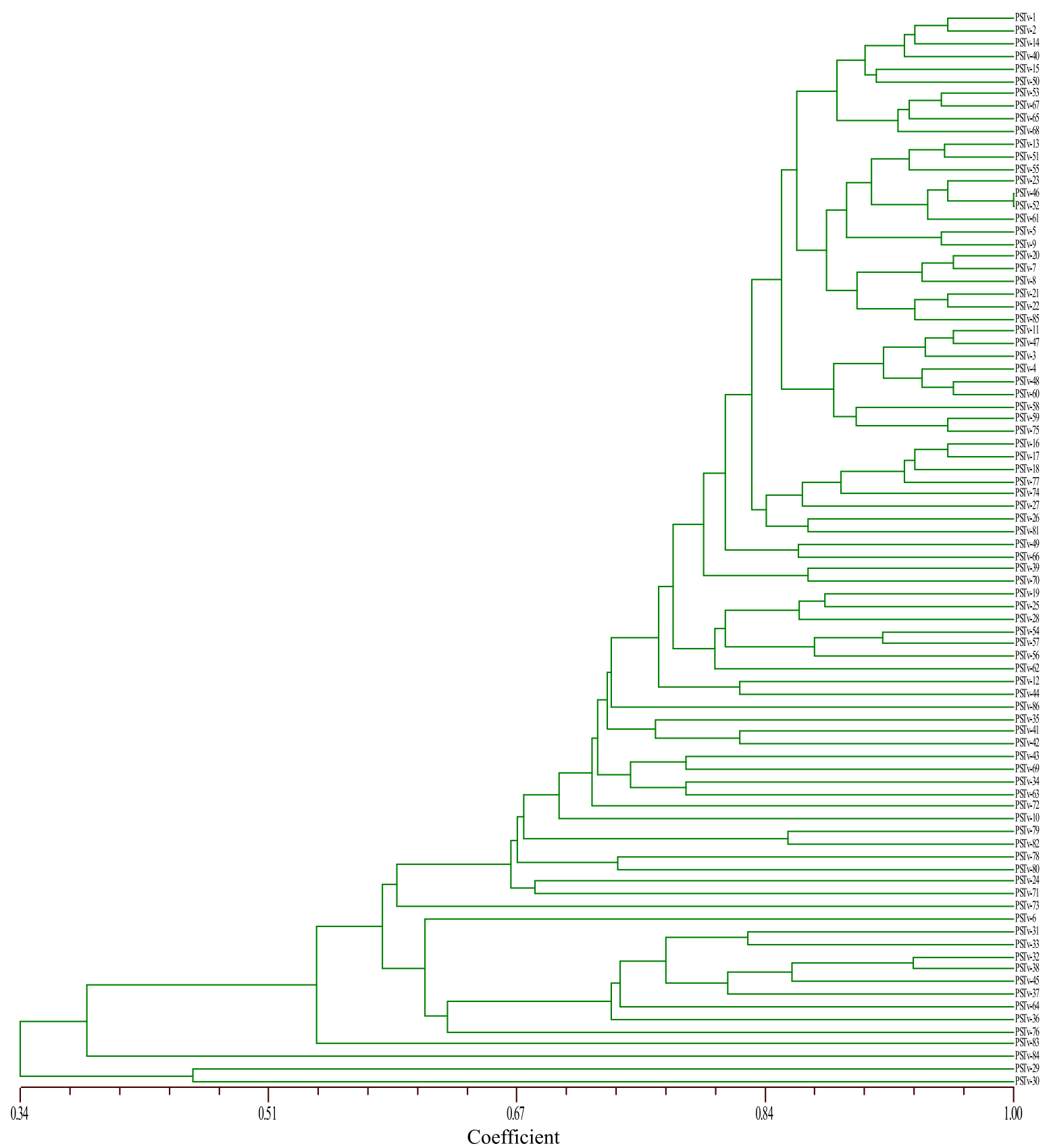

Fig. 1 Dendrogram showing the relationships among 86 Pst races identified based on their IT on the 29-Yr-gene differentials.

$\operatorname{Yr}(2, H V I I), \operatorname{Yr}(10, M o r)$ or $\operatorname{Yr}(7,22,23) ; \operatorname{Yr} 8$ and $\operatorname{YrSK}$ or $\operatorname{Yr}(17,29) ; \operatorname{Yr} 15$ or $\operatorname{Yr}(17,29)$ and $\operatorname{YrSK}$ or $\operatorname{Yr}(7,22,23) ; \operatorname{Yr}(17,29)$ or $\operatorname{Yr} 18$ and $\operatorname{Yr} 25$, YrSu, or $\operatorname{Yr}(8,19) ; \operatorname{Yr} 18$ and $Y r 24, \operatorname{Yr} 27, \operatorname{YrSK}$, Yr15; $Y r 24$ and $\operatorname{Yr}(2, H V I I)$, or $\operatorname{Yr}(7,22,23) ; \operatorname{Yr} 25$ and $Y r 8, Y r 26, Y r 30, Y r S K, \operatorname{Yr}(7,25) ; \operatorname{Yr}(2, H V I I)$ or $\operatorname{Yr}(7,22,23) ; \operatorname{Yr}(7,25)$ and $Y r 32, Y r S u, Y r S P$, $\operatorname{Yr}(8,19), \operatorname{Yr}(2, H V I I), \operatorname{Yr}(10, M o r) ; \operatorname{YrSK}$ and $\operatorname{Yr} 9$,
$\operatorname{Yr17}, \operatorname{YrSP}, \operatorname{YrSu}, \operatorname{Yr}(8,19)$; and $\operatorname{Yr}(7,22,23)$ and Yr11, Yr26 or Yr30, indicated with blue color in Fig. 2. None of the isolates was virulent to Yr5 and $\operatorname{Yr} 10$, and avirulence to these two genes was highly associated (1.00). The remaining pairwise associations were positive but not high (ranged from 0.01-0.49), indicated with green color in Fig. 2. 
Table 3 Virulence frequencies of Puccinia striiformis population on $Y r$ genes and their distribution.

\begin{tabular}{|c|c|c|c|}
\hline Yr Gene & $\begin{array}{c}\text { No. of } \\
\text { isolates }\end{array}$ & $\begin{array}{l}\text { Virulence } \\
\text { freq. (\%) }\end{array}$ & Distribution of isolates* \\
\hline Yr5 & 0 & 0 & None \\
\hline Yr10 & 0 & 0 & None \\
\hline Yr24 & 1 & 0.8 & CX(1) \\
\hline Yr15 & 2 & 1.6 & $\operatorname{SC}(2)$ \\
\hline Yr3 & 21 & 16.8 & CX(1), DL(1), KM(2), LC(3), LJ(1), QJ(4), SC(3), YX(4), ZT(2) \\
\hline Yr27 & 30 & 24.0 & CX(4), KM(2), LC(6), LJ(1), QJ(5), SC(7), WS(2), YX(1), ZT(2) \\
\hline $\operatorname{Yr}(7,22,23)$ & 30 & 24.0 & CX(6), DL(3), HH(2), KM(4), LC(6), SC(4), WS(1), YX(3), ZT(1) \\
\hline $\operatorname{Yr}(2, H V I I)$ & 59 & 47.2 & CX(7), DL(5), HH(3), KM(2), LC(11), LJ(5), NJ(2), QJ(6), SC(8), WS(4), YX(5), ZT(1) \\
\hline $\mathrm{YrSK}$ & 92 & 73.6 & CX(13), DL(2), HH(4), KM(5), LC(19), LJ(6), NJ(2), QJ(11), SC(9), WS(8), YX(11), ZT(2) \\
\hline Yr7 & 96 & 76.8 & CX(12), DL(3), HH(4), KM(7), LC(13), LJ(7), NJ(2), QJ(14), SC(9), WS(8), YX(16), ZT(1) \\
\hline Yr11 & 100 & 80.0 & CX(10), DL(1), HH(3), KM(6), LC(16), LJ(3), NJ(2), QJ(16), SC(15), WS(9), YX(18), ZT(1) \\
\hline $\operatorname{Yr}(8,19)$ & 102 & 81.6 & CX(8), DL(6), HH(2), KM(7), LC(18), LJ(1), NJ(2), QJ(15), SC(15), WS(10), YX(16), ZT(2) \\
\hline $\operatorname{Yr} 9$ & 103 & 82.4 & CX(12), DL(5), HH(4), KM(6), LC(16), LJ(2), NJ(2), QJ(16), SC(13), WS(8), YX(18), ZT(1) \\
\hline Yr8 & 105 & 84.0 & CX(10), DL(7), HH(3), KM(7), LC(17), LJ(5), NJ(2), QJ(16), SC(15), WS(8), YX(14), ZT(2) \\
\hline Yr25 & 105 & 84.0 & CX(11), DL(6), HH(2), KM(7), LC(16), LJ(2), NJ(2), QJ(16), SC(14), WS(11), YX(16), ZT(2) \\
\hline Yr30 & 105 & 84.0 & CX(11), DL(2), HH(3), KM(7), LC(18), LJ(7), NJ(2), QJ(16), SC(14), WS(7), YX(17), ZT(1) \\
\hline $\operatorname{Yr}(10, M o r)$ & 106 & 84.8 & CX(11), DL(6), HH(3), KM(6), LC(18), LJ(2), NJ(2), QJ(16), SC(15), WS(9), YX(16), ZT(2) \\
\hline $\mathrm{YrSu}$ & 106 & 84.8 & CX(10), DL(5), HH(2), KM(7), LC(16), LJ(4), NJ(2), QJ(16), SC(15), WS(10), YX(17), ZT(2) \\
\hline Yr32 & 107 & 85.6 & CX(10), DL(4), HH(4), KM(6), LC(18), LJ(6), NJ(2), QJ(16), SC(15), WS(9), YX(15), ZT(2) \\
\hline Yr17 & 108 & 86.4 & CX(11), DL(5), HH(4), KM(7), LC(19), LJ(1), NJ(2), QJ(16), SC(14), WS(9), YX(18), ZT(2) \\
\hline YrSP & 113 & 90.4 & CX(11), DL(7), HH(4), KM(7), LC(18), LJ(2), NJ(2), QJ(16), SC(15), WS(11), YX(18), ZT(2) \\
\hline Yr6 & 116 & 92.8 & CX(15), DL(3), HH(4), KM(8), LC(18), LJ(7), NJ(2), QJ(15), SC(15), WS(11), YX(17), ZT(1) \\
\hline Yr18 & 117 & 93.6 & CX(12), DL(7), HH(4), KM(7), LC(17), LJ(7), NJ(2), QJ(16), SC(15), WS(10), YX(18), ZT(2) \\
\hline YrA & 118 & 94.4 & CX(13), DL(6), HH(4), KM(7), LC(19), LJ(7), NJ(2), QJ(16), SC(15), WS(10), YX(18), ZT(1) \\
\hline $\operatorname{Yr}(7,25)$ & 119 & 95.2 & CX(16), DL(6), HH(4), KM(8), LC(18), LJ(7), NJ(2), QJ(16), SC(13), WS(10), YX(18), ZT(1) \\
\hline Yr26 & 119 & 95.2 & CX(15), DL(5), HH(4), KM(8), LC(18), LJ(7), NJ(2), QJ(16), SC(15), WS(10), YX(17), ZT(2) \\
\hline Yr1 & 120 & 96.0 & CX(15), DL(7), HH(4), KM(7), LC(18), LJ(7), NJ(2), QJ(16), SC(15), WS(11), YX(16), ZT(2) \\
\hline Yr2 & 123 & 98.4 & CX(16), DL(6), HH(4), KM(8), LC(19), LJ(7), NJ(2), QJ(16), SC(15), WS(11), YX(18), ZT(1) \\
\hline $\operatorname{Yr}(17,29)$ & 123 & 98.4 & CX(15), DL(7), HH(4), KM(8), LC(19), LJ(7), NJ(2), QJ(16), SC(15), WS(10), YX(18), ZT(2) \\
\hline
\end{tabular}

* Number in ( ) = number of isolates. Chuxiong (CX), Dali (DL), Honghe (HH), Kunming (KM), Lincang (LC), Lijiang (LJ), Nujiang (NJ), Qujing (QJ), Wenshan (WS), Yuxi (YX), Zhaotong (ZT), Sichuan (SC).

\section{DISCUSSION}

Stripe rust of wheat as the fungal disease is a significant yield-limiting factor in commercial wheat, incited by $P$. striiformis f. sp. tritici. Stripe rust considered a cosmopolitan disease due to the dynamic nature of its causal agent since it is converted from the disease of cold weather to the disease of variable ones. The annual survey of wheat stripe rust was conducted throughout the growing season 2017/18 of wheat crop in Yunnan and Sichuan provinces in China. Eighty-six virulence races characterized from 125 isolates were collected from 11 counties of Yunnan and one county of Sichuan, with the virulence frequencies ranged from $0.8-8.8 \%$. Races v1 and v2 were the most widely distributed races and were detected in five counties owing to their highly aggressive. The rest of races appeared with lower frequencies. Similar results were reported by Ali et $\mathrm{al}^{28}$ and Shahin et $\mathrm{al}^{29}$, who confirmed the predominance of stripe rust races $0 \mathrm{E} 0,6 \mathrm{E} 4,70 \mathrm{E} 20$, and 128E28 in Egypt.

The predominance of stripe rust disease at Lincang and Yuxi was relatively high, and these high virulence frequencies could be attributed to the existence of weather conditions, being suitable for disease dispersal and dissemination. The obtained results indicated the excellent performance of $\operatorname{Yr} 5$, Yr10, since it could not be attacked by either of the tested races all over the growing season (with 100\% efficacy); likewise, $\operatorname{Yr} 15$ and Yr24 occupied the second rank. Both Yr5 and Yr15 previously showed a high level of resistance to stripe rust in China, Iran, Turkey, North America, and Africa ${ }^{2,30}$.

Interestingly, the virulence frequencies for $\mathrm{Yr} 24$ and $\mathrm{Yr} 26$ were different, $0.8 \%$ and $95.2 \%$, respectively. The Yr24 and Yr26 genes isolated independently were found to be located in the centromere region of chromosome $1 \mathrm{~B}^{31,32}$, and were suggested to be a single gene. The significant difference in virulence frequencies to $\mathrm{Yr} 24$ and $\mathrm{Yr} 26$ indicated that these were not one gene but two linked genes. The Yr10 was located on chromosome $1 \mathrm{BL}^{33}$, while the $\mathrm{Yr} 5$ gene existed in chromosome $2 \mathrm{BL}^{34}$. The perfect correlation between $\operatorname{Yr} 5$ and $\mathrm{Yr} 10$ genes despite being at different chromosomes suggests that posttranslational interaction between these two genes occur.

In cluster analysis, the races were divided into two clusters. Cluster-I comprises two races v29 and v30 that had relatively narrow virulence spectra while Cluster-II comprises 84 races that had broad virulence spectra. The $\varphi$ coefficient of associa- 


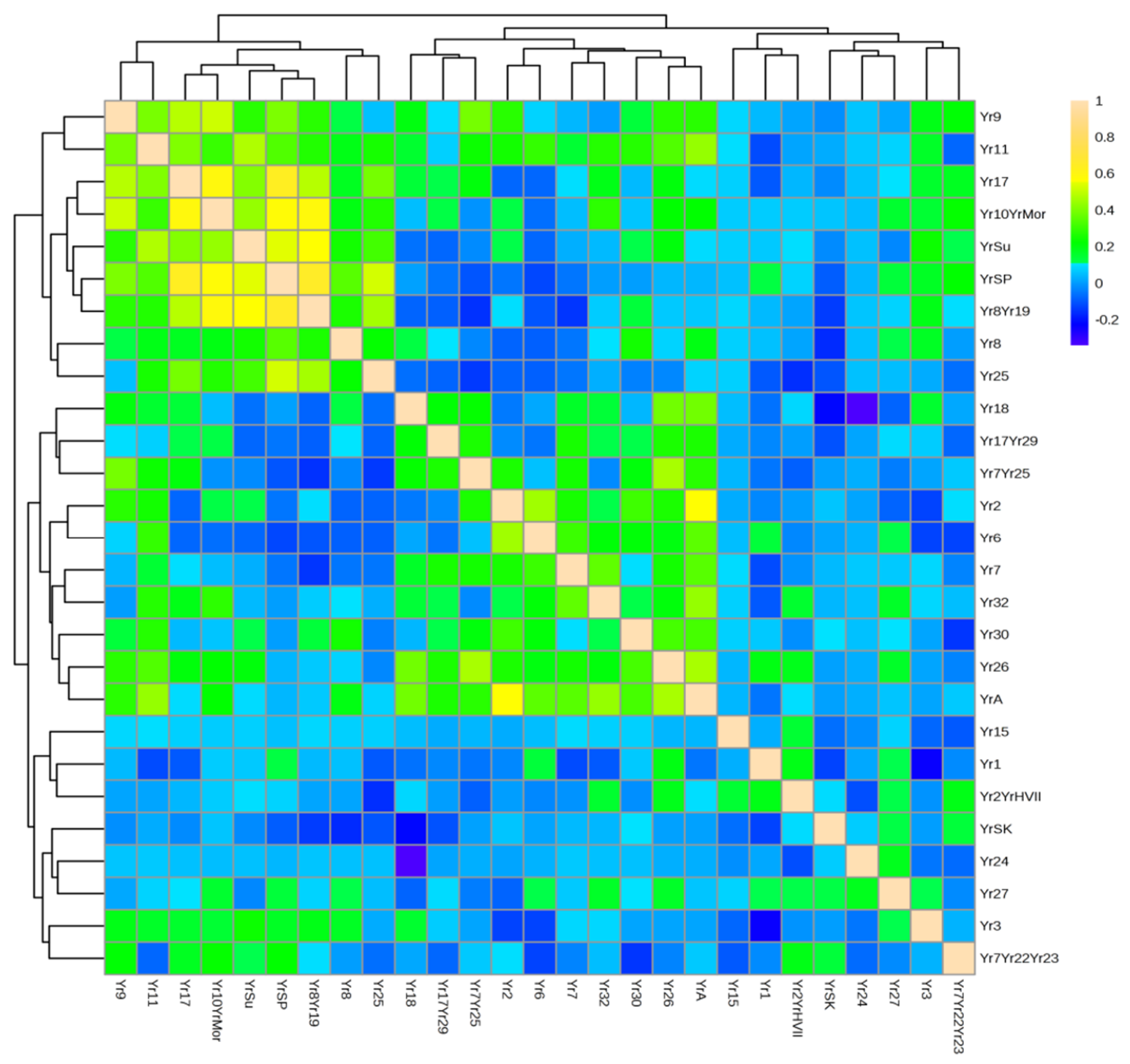

Fig. 2 Correlation coefficients between 27 avirulence/virulence loci of $P$. striiformis $\mathrm{f}$. sp. tritici. The avirulence genes are represented by their corresponding resistance $\mathrm{Yr}$ genes.

tion between virulence to the 29-Yr-gene differentials showed highly positive correlation identified between virulence to $\operatorname{YrSP}$ and $\operatorname{Yr}(8,19)$ or $\operatorname{Yr} 17$; $\operatorname{Yr}(10, M o r)$ and $\operatorname{Yr} 17, \operatorname{Yr}(8,19)$ or $\operatorname{YrSP}$. The remaining pairwise associations were moderate or have negative correlation except for $\operatorname{Yr} 5$ and $\operatorname{Yr} 10$ that were highly associated and resistant to virulence races. Similar results were reported by Li et al ${ }^{35,36}$. The virulence patterns revealed from this study can guide the wheat breeding program to develop resistant cultivars.

\section{CONCLUSION}

Survey of wheat yellow rust pathotypes using 29-Yrgene differential lines is significant in characterizing virulence variation, the geographical distribution of virulence isolates, and the way yellow rust isolates change in response to host selection. Out of 86 characterized Pst races, two races (v1 and v2) were widely distributed in Yunnan and Sichuan provinces of China. Based on the virulence spectrum, the 86 races were grouped into two clusters. ClusterI included only two races (v29 and v30) with a narrow virulence spectrum and cluster-II comprised 84 races with broad virulence spectrum. The four 
Yr genes (Yr5, Yr10, Yr15, and Yr24) were found to be effective against all tested virulent Pst races. This activity should be carried out in all wheat growing seasons using rust survey and planting of wheat rust trap nurseries at different locations in Yunnan province; this will supply timely warning to wheat breeders about the change in the virulence of $P$ striiformis pathotypes. Thus, it will be essential to avert future yellow rust epidemics and reduce yearly losses of the commercial wheat varieties grown in Yunnan, China.

Acknowledgements: This study was supported by the National Natural Science Foundation of China (31560490). The special funding was from the National Key R\&D Program of China (2018YFD0200500).

\section{Appendix A. Supplementary data}

Supplementary data associated with this article can be found at http://dx.doi.org/10.2306/ scienceasia1513-1874.2019.45.572.

\section{REFERENCES}

1. Rehman AU, Sajjad M, Khanand SH, Ahmad N (2013) Prospects of wheat breeding for durable resistance against brown, yellow, and black rust fungi. Int J Agric Biol 15, 1209-1220.

2. Chen XM (2005) Epidemiology and control of stripe rust (Puccinia striiformis f. sp. tritici) on wheat. Can J Plant Pathol 27, 314-337.

3. Wan AM, Chen XM, He ZH (2007) Wheat stripe rust in China. Aust J Agric Res 58, 605-619.

4. Yang HA, Stubbs RW (1990) Gene postulation for wheat stripe rust resistance on Chinese differential hosts. Acta Phys Sin 17, 67-72.

5. Bansal UK, Hayden MJ, GillMB, Bariana HS (2010) Chromosome location of an uncharacterized stripe rust resistance gene in wheat. Euphy 171, 121-127.

6. Chen WQ, Wu LR, Liu TG, Xu SC (2009) Race dynamics, diversity, and virulence evolution in Puccinia striiformis f. sp. tritici, the causal agent of wheat stripe rust in China from 2003 to 2007. Plant Dis 93, 1093-1101.

7. Wan AM, Wu LR, Jia QZ, Jin SL, Li GB, Wang BT, Yao G, Yang JX, et al (2003) Pathogenic changes of stripe rust fungus of wheat in China during 19972001. Acta Phyt Sinica 33, 261-266. [in Chinese]

8. Zhou JY, Li MJ, Lü JP (2006) Deduction of preliminary base of pathogen of wheat stripe rust in China. In: Proc of Annual Meeting Society of Chinese Plant Protection 2006, Beijing, China, pp 141-146.

9. Ali S, Gladieux P, Leconte M, Gautier A, Justesen AF, Hovmøller MS, Enjabert J,bVallavieille-Pope C (2014) Origin, migration routes and worldwide population genetic structure of the wheat yellow rust pathogen Puccinia striiformis f. sp. tritici. PLoS Pathog 10, ID e1003903.

10. Wan AM (2003) Differentials and nomenclature of races of Puccinia striiformis f. sp. tritici Eriksson. Acta Phyt Sinica 33, 481-486. [in Chinese]

11. Wan AM, Chen XM (2014) Virulence characterization of Puccinia striiformis $\mathrm{f}$. sp. tritici using a new set of Yr single-gene line differentials in the United States in 2010. Plant Dis 98, 1534-1542.

12. Hu XP, Wang BT, Kang ZS (2014) Research progress on virulence variation of Puccinia striiformis f. sp. tritici in China. J Tritceae Crop 34, 709-716. [in Chinese]

13. Chen XM, Penman L, Wan AM, Cheng P (2010) Virulence races of Puccinia striiformis $\mathrm{f}$. sp. tritici in 2006 and 2007 and development of wheat stripe rust and distributions, dynamics, and evolutionary relationships of races from 2000 to 2007 in the United States. Can J Plant Pathol 32, 315-333.

14. Stubbs RW (1985) Stripe rust. In: Roelfs AP, Bushnell WR (eds) The Cereal Rusts. Diseases, Distribution, Epidemiology, and Control, Academic Press, Orlando, pp 61-101.

15. Wan AM, Zhao ZH, Chen XM, He ZH, Jin SL, Jia QZ, Yao G, Yang JX, et al (2004) Wheat stripe rust epidemics and virulence of Puccinia striiformis $\mathrm{f}$. sp. tritici in China in 2002. Plant Dis 88, 896-904.

16. Wellings CR, Singh RP, McIntosh RA, Pretorius ZA (2004) The development and application of nearisogenic lines for the stripe (yellow) rust pathosystem. In: Proc 11th Int Cereal Rusts and Powdery Mildew, Norwich, England.

17. McIntosh RA, Dubcovsky J, Rogers WJ, Morris C, Appels R, Xia XC (2013) Wheat Gene Catalog 2013, available at wheat.pw.usda.gov/GG2/Triticum/wgc/ 2013/.

18. Chen W, Wellings C, Chen X, Kang Z, Liu T (2014) Wheat stripe (yellow) rust caused by Puccinia striiformis f. sp. tritici. Mol Plant Pathol 15, 433-446.

19. Ellis JG, Lagudah ES, Spielmeyer W, Dodds PN (2014) The past, present, and future of breeding rust-resistant wheat. Front Plant Sci 5, ID 641.

20. Sørensen CK, Hovmøller MS, Leconte M, Dedryver F, de Vallavieille-Pope C (2014) New races of Puccinia striiformis found in Europe reveal race specificity of long-term effective adult plant resistance in wheat. Phytopathology 104, 1042-1051.

21. McIntosh RA, Wellings CR, Park RF (1995) Wheat Rusts: An Atlas of Resistance Genes, Kluwer, Dordrecht.

22. Roelfs A, Singh R, Saari E (1992) Rust Diseases of Wheat: Concepts and Methods of Disease Management, CIMMYT, Mexico.

23. El-Orabey WM, Sallam ME, Omara RI, Abd El-Malik NI (2015) Geographical distribution of Puccinia triticina physiologic races in Egypt during 2012-2014 growing seasons. Afr J Agric Res 10, 4193-4203. 
24. Rohlf FJ (2008) NTS YSpc: Numerical Taxonomy System, ver. 2.20, Exeter Publishing, New York.

25. Sokal RR, Rohlf FJ (1995) Biometry, W. H. Freeman, New York.

26. Chen XM, Line RF, Leung H (1993) Relationship between virulence variation and DNA polymorphism in Puccinia striiformis. Phytopathology 83, 1489-1497.

27. Wan AM, Chen XM, Yuen J (2016) Races of Puccinia striiformis f. sp. tritici in the United States in 2011 and 2012 and comparison with races in 2010. Plant Dis 100, 966-975.

28. Ali S, Rodriguez-Algaba J, Thach T, Sorensen CK, Hansen J, Lassen P, Nazari K, Hodson DP, et al (2017) Yellow rust epidemics worldwide were caused by pathogen races from divergent genetic lineages. Front Plant Sci 8, ID 1057.

29. Shahin AA, Abu-Aly AA, Shahin SI (2015) Virulence and diversity of wheat stripe rust pathogen in Egypt. J Am Sci 11, 47-52.

30. Afshari F (2008) Prevalent pathotypes of Puccinia striiformis f. sp. tritici. Iran J Agric Sci Technol 10, 67-78.

31. McIntosh RA, Lagudah ES (2000) Cytogenetical studies in wheat. XVIII. Gene Yr24 for resistance to stripe rust. Plant Breed 119, 81-93.

32. Wang CM, Zhang YP, Han DJ, Kang ZS, Li GP, Cao AH, Chen PD (2008) SSR and STS markers for wheat stripe rust resistance gene Yr26. Euphyt 159, 359-366.

33. Singh R, Datta D, Priyamvada, Singh S, Tiwari R (2009) A diagnostic PCR based assay for stripe rust resistance gene Yr10 in wheat. Acta Phyt Entom Hung 44, 11-18.

34. Murphy LR, Santra D, Kidwell K, Yan G, Chen X, Campbell KG (2009) Linkage maps of wheat stripe rust resistance genes $\operatorname{Yr} 5$ and $Y r 15$ for use in markerassisted selection. Crop Sci 49, 1786-1790.

35. Li MJ, Yang ZL, Yang L, Gu ZL, Ji Y, Wei LL, Zhang YL, Zhang PH, et al (2016) Resistance of Yr genes and commercial wheat cultivars to yellow rust in Yunnan Province. Plant Prot 42, 161-168. [in Chinese]

36. Li MJ, Chen XM, Wan AM, Ding ML, Cheng JS (2018) Virulence characterization of stripe rust pathogen Puccinia striiformis f. sp. tritici population to 18 nearisogenic lines resistant to wheat yellow rust in Yunnan Province. J Plant Prot 45, 75-82. [in Chinese] 


\section{Appendix A. Supplementary data}

Table S1 Races of P. striiformis, their virulence formula, frequencies (\%), and distributions.

\begin{tabular}{|c|c|c|c|}
\hline Race & Virulence formula & Freq. & Distribution $^{\dagger}$ \\
\hline v1 & $\begin{array}{l}\operatorname{Yr} 1, \operatorname{Yr} 2, \operatorname{Yr} 6, \operatorname{Yr} 7, \operatorname{Yr} 8, \operatorname{Yr} 9, \operatorname{Yr} 11, \operatorname{Yr} 17, \operatorname{Yr} 18, \operatorname{Yr} 25, \operatorname{Yr} 26, \operatorname{Yr} 30, \operatorname{Yr} 32, \operatorname{Yr} A, \operatorname{YrSK}, \operatorname{YrSP}, \operatorname{YrSu}, \operatorname{Yr}(8,19), \\
\operatorname{Yr}(7,25), \operatorname{Yr}(10, M \operatorname{Mr}), \operatorname{Yr}(17,29)\end{array}$ & 8.8 & $\begin{array}{l}\text { KM, LC, QJ(3) } \\
\text { WS(3), YX(3) }\end{array}$ \\
\hline v2 & $\begin{array}{l}\operatorname{Yr1} 1, \operatorname{Yr} 2, \operatorname{Yr} 6, \operatorname{Yr} 7, \operatorname{Yr} 8, \operatorname{Yr} 9, \operatorname{Yr} 11, \operatorname{Yr} 17, \operatorname{Yr} 18, \operatorname{Yr} 25, \operatorname{Yr} 26, \operatorname{Yr} 30, \operatorname{Yr} 32, \operatorname{YrA}, \operatorname{YrSK}, \operatorname{YrSP}, \operatorname{YrSu}, \operatorname{Yr}(8,19), \\
\operatorname{Yr}(7,25), \operatorname{Yr}(2, H V I I), \operatorname{Yr}(10, M o r), \operatorname{Yr}(17,29)\end{array}$ & 8.0 & $\begin{array}{l}\mathrm{LC}(3), \mathrm{NJ}(2) \text {, } \\
\mathrm{QJ}(3), \mathrm{WS}, \mathrm{YX}\end{array}$ \\
\hline v3 & 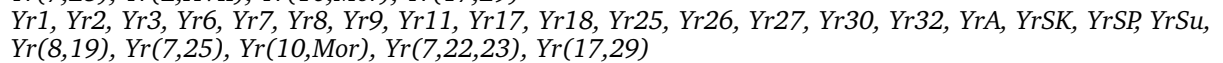 & 2.4 & SC, ZT, KM \\
\hline v4 & $\begin{array}{l}\operatorname{Yr1}, \operatorname{Yr2}, \operatorname{Yr6}, \operatorname{Yr} 7, \operatorname{Yr} 8, \operatorname{Yr} 9, \operatorname{Yr} 11, \operatorname{Yr17}, \operatorname{Yr} 18, \operatorname{Yr} 25, \operatorname{Yr} 26, \operatorname{Yr} 27, \operatorname{Yr} 30, \operatorname{Yr} 32, \operatorname{YrA}, \operatorname{YrSK}, \operatorname{YrSP}, \operatorname{YrSu}, \\
\operatorname{Yr}(8,19), \operatorname{Yr}(7,25), \operatorname{Yr}(10, M \operatorname{Mr}), \operatorname{Yr}(17,29)\end{array}$ & 2.4 & QJ(2), SC \\
\hline v5 & $\begin{array}{l}\text { Yr1, } \operatorname{Yr} 2, \operatorname{Yr} 6, \operatorname{Yr} 8, \operatorname{Yr} 9, \operatorname{Yr} 11, \operatorname{Yr} 17, \operatorname{Yr} 18, \operatorname{Yr} 25, \operatorname{Yr} 26, \operatorname{Yr} 30, \operatorname{Yr} 32, \operatorname{YrA}, \operatorname{YrSP}, \operatorname{YrSu}, \operatorname{Yr}(8,19), \operatorname{Yr}(7,25), \\
\operatorname{Yr}(10, M o r), \operatorname{Yr}(17,29)\end{array}$ & 2.4 & $\mathrm{SC}(3)$ \\
\hline v6 & Yr2, Yr6, Yr7, Yr11, Yr17, Yr18, Yr25, Yr26, Yr30, Yr32, YrA, YrSK, Yr(7,25), Yr(17,29) & 2.4 & CX, LC, KM \\
\hline v7 & $\begin{array}{l}\operatorname{Yr1}, \operatorname{Yr} 2, \operatorname{Yr} 3, \operatorname{Yr6}, \operatorname{Yr7}, \operatorname{Yr} 8, \operatorname{Yr} 9, \operatorname{Yr} 11, \operatorname{Yr} 17, \operatorname{Yr} 18, \operatorname{Yr} 25, \operatorname{Yr} 26, \operatorname{Yr} 27, \operatorname{Yr} 30, \operatorname{Yr} 32, \operatorname{YrA}, \operatorname{YrSK}, \operatorname{YrSP}, \operatorname{YrSu}, \\
\operatorname{Yr}(8,19), \operatorname{Yr}(7,25), \operatorname{Yr}(2, \mathrm{HVII}), \operatorname{Yr}(10, \operatorname{Mor}), \operatorname{Yr}(17,29)\end{array}$ & 1.6 & LC, SC \\
\hline v8 & $\begin{array}{l}\operatorname{Yr1} 1, \operatorname{Yr} 2, \operatorname{Yr} 3, \operatorname{Yr6}, \operatorname{Yr} 7, \operatorname{Yr} 8, \operatorname{Yr} 9, \operatorname{Yr} 11, \operatorname{Yr} 17, \operatorname{Yr} 18, \operatorname{Yr} 25, \operatorname{Yr} 26, \operatorname{Yr} 27, \operatorname{Yr} 30, \operatorname{Yr} 32, \operatorname{YrA}, \operatorname{YrSP}, \operatorname{YrSu}, \\
\operatorname{Yr}(8,19), \operatorname{Yr}(7,25), \operatorname{Yr}(10, M o r), \operatorname{Yr}(17,29)\end{array}$ & 1.6 & QJ(2) \\
\hline v9 & $\begin{array}{l}\operatorname{Yr1}, \operatorname{Yr} 2, \operatorname{Yr} 3, \operatorname{Yr} 6, Y r 8, \operatorname{Yr} 9, \operatorname{Yr} 11, \operatorname{Yr} 17, \operatorname{Yr18}, \operatorname{Yr} 25, \operatorname{Yr} 26, \operatorname{Yr} 30, \operatorname{Yr} 32, \operatorname{YrA}, \operatorname{YrSP}, \operatorname{YrSu}, \operatorname{Yr}(8,19), \operatorname{Yr}(7,25), \\
\operatorname{Yr}(10, M o r), \operatorname{Yr}(17,29)\end{array}$ & 1.6 & $\mathrm{KM}, \mathrm{YX}$ \\
\hline v10 & $\operatorname{Yr1} 1, \operatorname{Yr} 2, \operatorname{Yr} 6, \operatorname{Yr} 7, \operatorname{Yr} 8, \operatorname{Yr} 9, \operatorname{Yr} 17, \operatorname{Yr} 18, \operatorname{Yr} 26, \operatorname{Yr} 30, \operatorname{YrSP}, \operatorname{YrSu}, \operatorname{Yr}(8,19), \operatorname{Yr}(7,25), \operatorname{Yr}(10, M o r), \operatorname{Yr}(17,29)$ & 1.6 & $\mathrm{KM}, \mathrm{CX}$ \\
\hline v11 & $\begin{array}{l}\operatorname{Yr} 1, \operatorname{Yr2}, \operatorname{Yr} 6, \operatorname{Yr} 7, \operatorname{Yr} 8, \operatorname{Yr} 9, \operatorname{Yr} 11, \operatorname{Yr} 17, \operatorname{Yr} 18, \operatorname{Yr} 25, \operatorname{Yr} 26, \operatorname{Yr} 27, \operatorname{Yr} 30, \operatorname{Yr} 32, \operatorname{YrA}, \operatorname{YrSK}, \operatorname{YrSP}, \operatorname{YrSu}, \\
\operatorname{Yr}(8,19), \operatorname{Yr}(7,25), \operatorname{Yr}(2, \operatorname{HVII}), \operatorname{Yr}(10, \operatorname{Mor}), \operatorname{Yr}(7,22,23), \operatorname{Yr}(17,29)\end{array}$ & 1.6 & \\
\hline v12 & $\begin{array}{l}\operatorname{Yr1}, \operatorname{Yr2}, \operatorname{Yr6}, \operatorname{Yr} 7, \operatorname{Yr} 8, \operatorname{Yr} 9, \operatorname{Yr} 11, \operatorname{Yr} 17, \operatorname{Yr} 18, \operatorname{Yr} 25, \operatorname{Yr} 26, \operatorname{Yr} 30, \operatorname{Yr} 32, \operatorname{YrA}, \operatorname{YrSP}, \operatorname{YrSu}, \operatorname{Yr}(7,25), \\
\operatorname{Yr}(2, H V I I), \operatorname{Yr}(17,29)\end{array}$ & 1.6 & YX(2) \\
\hline v13 & $\begin{array}{l}\operatorname{Yr1} 1, \operatorname{Yr} 2, \operatorname{Yr} 6, \operatorname{Yr} 7, \operatorname{Yr} 8, \operatorname{Yr} 9, \operatorname{Yr11}, \operatorname{Yr17}, \operatorname{Yr} 18, \operatorname{Yr} 25, \operatorname{Yr} 26, \operatorname{Yr} 30, \operatorname{Yr} 32, \operatorname{YrA}, \operatorname{YrSP}, \operatorname{YrSu}, \operatorname{Yr}(8,19), \operatorname{Yr}(7,25), \\
\operatorname{Yr}(10, M \operatorname{Mr}), \operatorname{Yr}(7,22,23), \operatorname{Yr}(17,29)\end{array}$ & 1.6 & CX, YX \\
\hline v14 & $\begin{array}{l}\operatorname{Yr1}, \operatorname{Yr} 2, \operatorname{Yr} 6, \operatorname{Yr} 7, \operatorname{Yr} 8, \operatorname{Yr} 9, \operatorname{Yr11} 1, \operatorname{Yr17}, \operatorname{Yr} 18, \operatorname{Yr} 25, \operatorname{Yr} 26, \operatorname{Yr} 32, \operatorname{YrA}, \operatorname{YrSK}, \operatorname{YrSP}, \operatorname{YrSu}, \operatorname{Yr}(8,19), \operatorname{Yr}(7,25), \\
\operatorname{Yr}(2, H V I I), \operatorname{Yr}(10, M o r), \operatorname{Yr}(17,29)\end{array}$ & 1.6 & $\mathrm{HH}, \mathrm{SC}$ \\
\hline v15 & $\begin{array}{l}\operatorname{Yr1}, \operatorname{Yr} 2, \operatorname{Yr} 6, \operatorname{Yr} 7, \operatorname{Yr} 8, \operatorname{Yr} 9, \operatorname{Yr} 11, \operatorname{Yr17}, \operatorname{Yr} 18, \operatorname{Yr} 26, \operatorname{Yr} 30, \operatorname{Yr} 32, \operatorname{YrA}, \operatorname{YrSK}, \operatorname{YrSP}, \operatorname{YrSu}, \operatorname{Yr}(8,19), \operatorname{Yr}(7,25), \\
\operatorname{Yr}(10, M o r), \operatorname{Yr}(17,29)\end{array}$ & 1.6 & LC, YX \\
\hline v16 & $\begin{array}{l}\operatorname{Yr1}, \operatorname{Yr2}, \operatorname{Yr} 6, \operatorname{Yr} 8, \operatorname{Yr} 9, \operatorname{Yr} 11, \operatorname{Yr} 17, \operatorname{Yr} 18, \operatorname{Yr} 25, \operatorname{Yr} 26, \operatorname{Yr} 30, \operatorname{Yr} 32, \operatorname{YrA}, \operatorname{YrSK}, \operatorname{YrSP}, \operatorname{YrSu}, \operatorname{Yr}(8,19), \\
\operatorname{Yr}(7,25), \operatorname{Yr}(10, \operatorname{Mor}), \operatorname{Yr}(7,22,23), \operatorname{Yr}(17,29)\end{array}$ & 1.6 & $\mathrm{LC}(2)$ \\
\hline v17 & $\begin{array}{l}\operatorname{Yr1}, \operatorname{Yr} 2, \operatorname{Yr} 6, \operatorname{Yr} 8, \operatorname{Yr} 9, \operatorname{Yr} 11, \operatorname{Yr} 17, \operatorname{Yr} 18, \operatorname{Yr} 25, \operatorname{Yr} 26, \operatorname{Yr} 30, \operatorname{Yr} 32, \operatorname{YrA}, \operatorname{YrSK}, \operatorname{YrSP}, \operatorname{YrSu}, \operatorname{Yr}(8,19), \\
\operatorname{Yr}(7,25), \operatorname{Yr}(2, H V I I), \operatorname{Yr}(10, M \operatorname{Mr}), \operatorname{Yr}(7,22,23), \operatorname{Yr}(17,29)\end{array}$ & 1.6 & SC, LC \\
\hline v18 & $\begin{array}{l}\operatorname{Yr1}, \operatorname{Yr} 2, \operatorname{Yr} 6, \operatorname{Yr} 8, \operatorname{Yr} 9, \operatorname{Yr} 11, \operatorname{Yr} 17, \operatorname{Yr} 18, \operatorname{Yr} 25, \operatorname{Yr} 26, \operatorname{Yr} 30, \operatorname{Yr} 32, \operatorname{YrA}, \operatorname{YrSK}, \operatorname{YrSP}, \operatorname{YrSu}, \operatorname{Yr}(8,19), \\
\operatorname{Yr}(7,25), \operatorname{Yr}(2, \mathrm{HVII}), \operatorname{Yr}(10, M \operatorname{Mr}), \operatorname{Yr}(17,29)\end{array}$ & 1.6 & QJ, WS \\
\hline v19 & $\begin{array}{l}Y r 1, \operatorname{Yr} 2, \operatorname{Yr} 3, \operatorname{Yr} 6, \operatorname{Yr} 7, \operatorname{Yr} 8, \operatorname{Yr} 9, \operatorname{Yr} 17, \operatorname{Yr18}, \operatorname{Yr} 26, \operatorname{Yr} 32, \operatorname{YrA}, \operatorname{YrSK}, \operatorname{YrSP}, \operatorname{YrSu}, \operatorname{Yr}(8,19), \operatorname{Yr}(7,25), \\
\operatorname{Yr}(2, H V I I), \operatorname{Yr}(10, \operatorname{Mor}), \operatorname{Yr}(7,22,23), \operatorname{Yr}(17,29)\end{array}$ & 0.8 & DL \\
\hline v20 & $\begin{array}{l}\operatorname{Yr1}, \operatorname{Yr} 2, \operatorname{Yr} 3, \operatorname{Yr} 6, \operatorname{Yr} 7, \operatorname{Yr} 8, \operatorname{Yr} 9, \operatorname{Yr} 11, \operatorname{Yr} 17, \operatorname{Yr} 18, \operatorname{Yr} 25, \operatorname{Yr} 26, \operatorname{Yr} 27, \operatorname{Yr} 30, \operatorname{Yr} 32, \operatorname{Yr} A, \operatorname{YrSP}, \operatorname{YrSu}, \\
\operatorname{Yr}(8,19), \operatorname{Yr}(7,25), \operatorname{Yr}(2, H V I I), \operatorname{Yr}(10, M \operatorname{Mr}), \operatorname{Yr}(17,29)\end{array}$ & 0.8 & QJ \\
\hline v21 & $\begin{array}{l}\operatorname{Yr1}, \operatorname{Yr2}, \operatorname{Yr3}, \operatorname{Yr6}, \operatorname{Yr} 7, \operatorname{Yr} 8, \operatorname{Yr} 9, \operatorname{Yr11}, \operatorname{Yr} 17, \operatorname{Yr} 18, \operatorname{Yr} 25, \operatorname{Yr} 26, \operatorname{Yr} 30, \operatorname{Yr} 32, \operatorname{YrA}, \operatorname{YrSK}, \operatorname{YrSP}, \operatorname{YrSu}, \\
\operatorname{Yr}(8,19), \operatorname{Yr}(7,25), \operatorname{Yr}(10, M o r), \operatorname{Yr}(17,29)\end{array}$ & 0.8 & LC \\
\hline v22 & $\begin{array}{l}\operatorname{Yr} 1, \operatorname{Yr2}, \operatorname{Yr3}, \operatorname{Yr6}, \operatorname{Yr} 7, \operatorname{Yr} 8, \operatorname{Yr} 9, \operatorname{Yr} 11, \operatorname{Yr} 17, \operatorname{Yr} 18, \operatorname{Yr} 25, \operatorname{Yr} 26, \operatorname{Yr} 30, \operatorname{Yr} 32, \operatorname{YrA}, \operatorname{YrSP}, \operatorname{YrSu}, \operatorname{Yr}(8,19), \\
\operatorname{Yr}(7,25), \operatorname{Yr}(10, M o r), \operatorname{Yr}(17,29)\end{array}$ & 0.8 & SC \\
\hline v23 & $\begin{array}{l}\operatorname{Yr} 1, \operatorname{Yr2}, \operatorname{Yr} 3, \operatorname{Yr} 6, \operatorname{Yr} 7, \operatorname{Yr} 8, \operatorname{Yr} 9, \operatorname{Yr} 11, \operatorname{Yr} 17, \operatorname{Yr} 18, \operatorname{Yr} 25, \operatorname{Yr} 26, \operatorname{Yr} 30, \operatorname{Yr} 32, \operatorname{Yr} A, \operatorname{YrSP}, \operatorname{YrSu}, \operatorname{Yr}(8,19), \\
\operatorname{Yr}(7,25), \operatorname{Yr}(2, H V I I), \operatorname{Yr}(10, M o r), \operatorname{Yr}(17,29)\end{array}$ & 0.8 & QJ \\
\hline v24 & $\begin{array}{l}\operatorname{Yr} 1, \operatorname{Yr2}, \operatorname{Yr3}, \operatorname{Yr} 6, \operatorname{Yr} 7, \operatorname{Yr} 8, \operatorname{Yr} 9, \operatorname{Yr11}, \operatorname{Yr} 18, \operatorname{Yr} 26, \operatorname{Yr} 27, \operatorname{Yr} 30, \operatorname{YrA}, \operatorname{YrSK}, \operatorname{YrSP}, \operatorname{YrSu}, \operatorname{Yr}(7,25), \\
\operatorname{Yr}(2, H V I I), \operatorname{Yr}(17,29)\end{array}$ & 0.8 & LJ \\
\hline v25 & $\begin{array}{l}\operatorname{Yr1}, \operatorname{Yr} 2, \operatorname{Yr} 3, \operatorname{Yr} 6, \operatorname{Yr} 7, \operatorname{Yr} 9, \operatorname{Yr11}, \operatorname{Yr17}, \operatorname{Yr18}, \operatorname{Yr} 25, \operatorname{Yr} 26, \operatorname{Yr} 32, \operatorname{YrA}, \operatorname{YrSK}, \operatorname{YrSP}, \operatorname{YrSu}, \operatorname{Yr}(8,19), \operatorname{Yr}(7,25), \\
\operatorname{Yr}(2, H V I I), \operatorname{Yr}(10, M o r), \operatorname{Yr}(7,22,23), \operatorname{Yr}(17,29)\end{array}$ & 0.8 & CX \\
\hline v26 & $\begin{array}{l}\operatorname{Yr1}, \operatorname{Yr} 2, \operatorname{Yr} 3, \operatorname{Yr} 6, \operatorname{Yr} 8, \operatorname{Yr} 9, \operatorname{Yr} 11, \operatorname{Yr} 17, \operatorname{Yr} 18, \operatorname{Yr} 25, \operatorname{Yr} 26, \operatorname{Yr} 30, \operatorname{YrA}, \operatorname{YrSK}, \operatorname{YrSP}, \operatorname{YrSu}, \operatorname{Yr}(8,19), \operatorname{Yr}(7,25), \\
\operatorname{Yr}(10, M o r), \operatorname{Yr}(17,29)\end{array}$ & 0.8 & YX \\
\hline v27 & $\begin{array}{l}\operatorname{Yr1}, \operatorname{Yr2} 2, \operatorname{Yr} 3, \operatorname{Yr} 6, \operatorname{Yr} 8, \operatorname{Yr} 9, \operatorname{Yr} 11, \operatorname{Yr17}, \operatorname{Yr} 18, \operatorname{Yr} 26, \operatorname{Yr} 30, \operatorname{Yr} 32, \operatorname{YrA}, \operatorname{YrSK}, \operatorname{YrSP}, \operatorname{YrSu}, \operatorname{Yr}(8,19), \operatorname{Yr}(7,25), \\
\operatorname{Yr}(2, H V I I), \operatorname{Yr}(10, M o r), \operatorname{Yr}(17,29)\end{array}$ & 0.8 & LC \\
\hline v28 & $\begin{array}{l}\operatorname{Yr1} 1, \operatorname{Yr} 2, \operatorname{Yr} 3, \operatorname{Yr} 7, \operatorname{Yr} 8, \operatorname{Yr} 9, \operatorname{Yr} 11, \operatorname{Yr17}, \operatorname{Yr} 18, \operatorname{Yr} 26, \operatorname{Yr} 30, \operatorname{Yr} 32, \operatorname{YrA}, \operatorname{YrSK}, \operatorname{YrSP}, \operatorname{YrSu}, \operatorname{Yr}(8,19), \operatorname{Yr}(7,25), \\
\operatorname{Yr}(2, H V I I), \operatorname{Yr}(10, M o r), \operatorname{Yr}(7,22,23), \operatorname{Yr}(17,29)\end{array}$ & 0.8 & LC \\
\hline v29 & $\operatorname{Yr1}, \operatorname{Yr} 2, \operatorname{Yr} 6, \operatorname{YrSK}, \operatorname{Yr}(7,25), \operatorname{Yr}(17,29)$ & 0.8 & $\mathrm{CX}$ \\
\hline v30 & $Y r 1, Y r 2, Y$ & 0.8 & WS \\
\hline v31 & Yr1, Yr2, Yr6, Yr7, Yr18, Yr2 & 8 & LJ \\
\hline v32 & Yr1, Yr2, Yr6, Yr7, Yr18, Yr26, Yr30, Yr32, YrA, YrSK, Yr(7,25), Yr(2,HVII), Yr(17,29) & 0.8 & \\
\hline v33 & Yr1, Yr2, Yr6, Yr7, Yr11, Yr18, Yr26, Yr30, Yr32, YrA, YrSK, YrSu, Yr(7,25), $\operatorname{Yr}(2, H V I I), \operatorname{Yr}(17,29)$ & 0.8 & LJ \\
\hline v34 & $\begin{array}{l}\operatorname{Yr} 1, \operatorname{Yr} 2, \operatorname{Yr} 6, \operatorname{Yr} 7, \operatorname{Yr} 8, \operatorname{Yr} 17, \operatorname{Yr} 18, \operatorname{Yr} 25, \operatorname{Yr} 26, \operatorname{Yr} 27, \operatorname{Yr} 30, \operatorname{Yr} 32, \operatorname{YrA}, \operatorname{YrSP}, \operatorname{Yr}(8,19), \operatorname{Yr}(7,25), \\
\operatorname{Yr}(2, H V I I), \operatorname{Yr}(10, M o r), \operatorname{Yr}(7,22,23), \operatorname{Yr}(17,29)\end{array}$ & 0.8 & LC \\
\hline v35 & 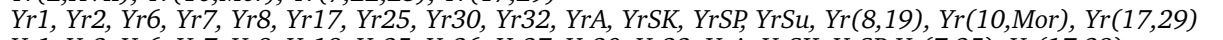 & & LC \\
\hline v36 & $Y r 1, Y r 2, Y r 6, Y r 7, Y r 8, Y r 1$ & & \\
\hline v37 & $Y r 1, Y r 2, Y r 6, Y r 7, Y r 8, Y r 18, Y r$ & 0.8 & \\
\hline v38 & Yr1, Yr2, Yr6, Yr7, Yr8, Yr18, Yr26, Yr30, Yr32, YrA, YrSK, Yr(7,25), Yr(2,HVII), Yr(17,29) & 0.8 & $\mathrm{CX}$ \\
\hline v39 & $\begin{array}{l}\operatorname{Yr} 1, \operatorname{Yr2}, \operatorname{Yr6}, \operatorname{Yr} 7, \operatorname{Yr} 8, \operatorname{Yr11}, \operatorname{Yr} 17, \operatorname{Yr} 18, \operatorname{Yr} 25, \operatorname{Yr} 26, \operatorname{Yr} 27, \operatorname{Yr} 30, \operatorname{Yr} 32, \operatorname{YrA}, \operatorname{YrSP}, \operatorname{YrSu}, \operatorname{Yr}(8,19), \\
\operatorname{Yr}(7,25), \operatorname{Yr}(10, M o r), \operatorname{Yr}(17,29)\end{array}$ & 0.8 & WS \\
\hline $\mathrm{v} 40$ & $\begin{array}{l}\operatorname{Yr1}, \operatorname{Yr2}, \operatorname{Yr} 6, \operatorname{Yr} 7, \operatorname{Yr} 8, \operatorname{Yr} 11, \operatorname{Yr} 17, \operatorname{Yr} 18, \operatorname{Yr} 25, \operatorname{Yr} 26, \operatorname{Yr} 30, \operatorname{Yr} 32, \operatorname{YrA}, \operatorname{YrSK}, \operatorname{YrSP}, \operatorname{YrSu}, \operatorname{Yr}(8,19), \\
\operatorname{Yr}(7,25), \operatorname{Yr}(2, H V I I), \operatorname{Yr}(10, M \operatorname{Mr}), \operatorname{Yr}(17,29)\end{array}$ & 0.8 & LJ \\
\hline v41 & $\begin{array}{l}\operatorname{Yr1}, \operatorname{Yr} 2, \operatorname{Yr6}, \operatorname{Yr} 7, \operatorname{Yr} 8, \operatorname{Yr11}, \operatorname{Yr} 18, \operatorname{Yr} 25, \operatorname{Yr} 26, \operatorname{Yr} 30, \operatorname{Yr} 32, \operatorname{YrA}, \operatorname{YrSK}, \operatorname{YrSP}, \operatorname{YrSu},(8,19), \operatorname{Yr}(2, H V I I), \\
\operatorname{Yr}(10, M \operatorname{Mr}), \operatorname{Yr}(17,29)\end{array}$ & 0.8 & SC \\
\hline
\end{tabular}


v42 Yr1, Yr2, Yr6, Yr7, Yr8, Yr11, Yr25, Yr26, Yr30, Yr32, YrA, YrSP, YrSu, Yr(8,19), Yr(7,25), Yr(10,Mor), $\operatorname{Yr}(7,22,23), \operatorname{Yr}(17,29)$

v43 Yr1, Yr2, Yr6, Yr7, Yr8, Yr9, Yr17, Yr18, Yr25, Yr26, Yr27,32, YrA, YrSK, YrSP, Yr(7,25), Yr(2,HVII), $\operatorname{Yr}(10, \operatorname{Mor}), \operatorname{Yr}(17,29)$

v44 Yr1, Yr2, Yr6, Yr7, Yr8, Yr9, Yr17, Yr18, Yr25, Yr26, Yr30, YrA, YrSP, YrSu, Yr(8,19), Yr(7,25), $\operatorname{Yr}(2, H V I I)$, $\operatorname{Yr}(7,22,23), \operatorname{Yr}(17,29)$

v45 Yr1, Yr2, Yr6, Yr7, Yr8, Yr9, Yr18, Yr26, Yr30, Yr32, YrA, YrSK, Yr(7,25), Yr(2,HVII), Yr(10,Mor), Yr(17,29)

v46 Yr1, Yr2, Yr6, Yr7, Yr8, Yr9, Yr11, Yr17, Yr18, Yr25, Yr26, Yr30, Yr32, YrA, YrSP, YrSu, Yr(8,19), Yr(7,25), $\operatorname{Yr}(2, H V I I), \operatorname{Yr}(10, M o r), \operatorname{Yr}(17,29)$

v47 Yr1, Yr2, Yr6, Yr7, Yr8, Yr9, Yr11, Yr17, Yr18, Yr25, Yr26, Yr27, Yr30, Yr32, YrA, YrSK, YrSP, YrSu, Yr (8,19), $\operatorname{Yr}(7,25), \operatorname{Yr}(10, M o r), \operatorname{Yr}(7,22,23), \operatorname{Yr}(17,29)$

v48 Yr1, Yr2, Yr6, Yr7, Yr8, Yr9, Yr11, Yr17, Yr18, Yr25, Yr26, Yr27, Yr30, Yr32, YrA, YrSK, YrSP, YrSu, Yr (8,19), $\operatorname{Yr}(7,25), \operatorname{Yr}(2, H V I I), \operatorname{Yr}(10, M \operatorname{Mor}), \operatorname{Yr}(17,29)$

v49 Yr1, Yr2, Yr6, Yr7, Yr8, Yr9, Yr11, Yr17, Yr18, Yr25, Yr26, Yr30, Yr32, YrA, YrSK, YrSP, Yr(8,19), Yr(7,25), $\operatorname{Yr}(17,29)$

v50 Yr1, Yr2, Yr6, Yr7, Yr8, Yr9, Yr11, Yr17, Yr18, Yr25, Yr26, Yr30, Yr32, YrA, YrSK, YrSP, YrSu, Yr(7,25), $\operatorname{Yr}(10, M o r), \operatorname{Yr}(17,29)$

v51 Yr1, Yr2, Yr6, Yr7, Yr8, Yr9, Yr11, Yr17, Yr18, Yr25, Yr26, Yr30, Yr32, YrA, YrSP, YrSu, Yr(8,19), $\operatorname{Yr}(7,25)$, $\operatorname{Yr}(10, M o r), \operatorname{Yr}(17,29)$

v52 Yr1, Yr2, Yr6, Yr7, Yr8, Yr9, Yr11, Yr17, Yr18, Yr25, Yr26, Yr30, Yr32, YrA, YrSP, YrSu, Yr(8,19), $\operatorname{Yr}(7,25)$, $\operatorname{Yr}(2, H V I I), \operatorname{Yr}(10, M o r), \operatorname{Yr}(17,29)$

v53 Yr1, Yr2, Yr6, Yr7, Yr8, Yr9, Yr11, Yr17, Yr18, Yr25, Yr26, Yr30, YrA, YrSK, YrSP, YrSu, Yr(8,19), Yr(7,25), $\operatorname{Yr}(10, M o r), \operatorname{Yr}(17,29)$

v54 Yr1, Yr2, Yr6, Yr7, Yr8, Yr9, Yr11, Yr17, Yr18, Yr25, Yr26, Yr32, YrA, YrSK, YrSP, YrSu, Yr(7,25), Yr(2,HVII), $\operatorname{Yr}(10, M o r), \operatorname{Yr}(7,22,23), \operatorname{Yr}(17,29)$

v55 Yr1, Yr2, Yr6, Yr7, Yr8, Yr9, Yr11, Yr17, Yr18, Yr25, Yr26, Yr32, YrA, YrSP, YrSu, Yr(8,19), $\operatorname{Yr}(7,25)$, $\operatorname{Yr}(10$, Mor $), \operatorname{Yr}(17,29)$

v56 Yr1, Yr2, Yr6, Yr7, Yr8, Yr9, Yr11, Yr17, Yr18, Yr25, Yr26, YrA, YrSK, YrSP, YrSu, Yr(7,25), Yr(10,Mor), $\operatorname{Yr}(7,22,23), \operatorname{Yr}(17,29)$

v57 Yr1, Yr2, Yr6, Yr7, Yr8, Yr9, Yr11, Yr17, Yr18, Yr26, Yr30, Yr32, YrA, YrSK, YrSP, YrSu, Yr(7,25), Yr(2,HVII), $\operatorname{Yr}(10, M o r), \operatorname{Yr}(7,22,23), \operatorname{Yr}(17,29)$

v58 Yr1, Yr2, Yr6, Yr7, Yr8, Yr9, Yr11, Yr17, Yr24, Yr25, Yr26, Yr27, Yr30, Yr32, YrA, YrSK, YrSP, YrSu, Yr (8, 19), $\operatorname{Yr}(7,25), \operatorname{Yr}(10, M o r), \operatorname{Yr}(17,29)$

v59 Yr1, Yr2, Yr6, Yr7, Yr8, Yr9, Yr11, Yr17, Yr25, Yr26, Yr27, Yr30, Yr32, YrA, YrSK, YrSP, YrSu, Yr (8,19), $\operatorname{Yr}(7,25), \operatorname{Yr}(2, H V I I), \operatorname{Yr}(10, M \operatorname{Mr}), \operatorname{Yr}(17,29)$

v60 Yr1, Yr2, Yr6, Yr7, Yr8, Yr9, Yr11, Yr15, Yr17, Yr18, Yr25, Yr26, Yr27, Yr30, Yr32, YrA, YrSK, YrSP, YrSu, $\operatorname{Yr}(8,19), \operatorname{Yr}(7,25), \operatorname{Yr}(2, H V I I), \operatorname{Yr}(10, M o r), \operatorname{Yr}(17,29)$

v61 Yr1, Yr2, Yr6, Yr7, Yr8, Yr9, Yr11, Yr15, Yr17, Yr18, Yr25, Yr26, Yr30, Yr32, YrA, YrSP, YrSu, Yr(8,19), $\operatorname{Yr}(7,25), \operatorname{Yr}(2, H V I I), \operatorname{Yr}(10, M \operatorname{Mor}), \operatorname{Yr}(17,29)$

v62 Yr1, Yr2, Yr6, Yr7, Yr9, Yr17, Yr18, Yr25, Yr26, Yr32, YrA, YrSP, YrSu, Yr(8,19), Yr(7,25), Yr(10,Mor), $\operatorname{Yr}(7,22,23), \operatorname{Yr}(17,29)$

v63 Yr1, Yr2, Yr6, Yr7, Yr9, Yr17, Yr18, Yr26, Yr30, Yr32, YrA, YrSK, YrSP, Yr(7,25), Yr(2,HVII), Yr(10,Mor), $\operatorname{Yr}(7,22,23), \operatorname{Yr}(17,29)$

v64 Yr1, Yr2, Yr6, Yr7, Yr9, Yr18, Yr26, Yr27, Yr30, Yr32, YrA, YrSK, Yr(7,25), $\operatorname{Yr}(10, M o r), \operatorname{Yr}(17,29)$

v65 Yr1, Yr2, Yr6, Yr7, Yr9, Yr11, Yr17, Yr18, Yr25, Yr26, Yr30, Yr32, YrA, YrSK, YrSP, YrSu, Yr(8,19), Yr(7,25), $\operatorname{Yr}(10, M o r), \operatorname{Yr}(17,29)$

v66 Yr1, Yr2, Yr6, Yr7, Yr9, Yr11, Yr17, Yr18, Yr25, Yr26, Yr30, Yr32, YrA, YrSP, Yr(8,19), $\operatorname{Yr}(7,25), \operatorname{Yr}(10, M o r)$, $\operatorname{Yr}(17,29)$

v67 Yr1, Yr2, Yr6, Yr7, Yr9, Yr11, Yr17, Yr18, Yr25, Yr26, Yr30, YrA, YrSK, YrSP, YrSu, Yr(8,19), $\operatorname{Yr}(7,25)$, $\operatorname{Yr}(10, M o r), \operatorname{Yr}(17,29)$

v68 Yr1, Yr2, Yr6, Yr7, Yr9, Yr11, Yr17, Yr18, Yr25, Yr26, Yr30, YrA, YrSK, YrSP, YrSu, Yr(8,19), $\operatorname{Yr}(7,25)$, $\operatorname{Yr}(2, H V I I), \operatorname{Yr}(10, M o r), \operatorname{Yr}(17,29)$

v69 Yr1, Yr2, Yr6, Yr7, Yr9, Yr11, Yr17, Yr18, Yr26, Yr27, Yr32, YrA, YrSP, YrSu, Yr(8,19), Yr(7,25), Yr(2,HVII), $\operatorname{Yr}(10, M o r), \operatorname{Yr}(7,22,23), \operatorname{Yr}(17,29)$

v70 Yr1, Yr2, Yr6, Yr8, Yr11, Yr17, Yr18, Yr25, Yr26, Yr27, Yr30, Yr32, YrA, YrSP, YrSu, Yr(8,19), Yr(2,HVII), $\operatorname{Yr}(10, M o r), \operatorname{Yr}(17,29)$

v71 Yr1, Yr2, Yr6, Yr8, Yr11, Yr18, Yr26, Yr25, Yr30, YrA, YrSP, YrSu, Yr(8,19), Yr(7,25), Yr(2,HVII), Yr(17,29)

v72 Yr1, Yr2, Yr6, Yr8, Yr9, Yr17, Yr18, Yr25, Yr26, Yr27, Yr30, YrA, YrSK, YrSP, Yr(8,19), Yr(7,25), Yr(10,Mor), $\operatorname{Yr}(17,29)$

v73 Yr1, Yr2, Yr6, Yr8, Yr9, Yr18, Yr25, Yr32, YrA, YrSP, $\operatorname{Yr}(8,19), \operatorname{Yr}(2, H V I I), \operatorname{Yr}(10, M o r), \operatorname{Yr}(7,22,23), \operatorname{Yr}(17,29)$

v74 Yr1, Yr2, Yr6, Yr8, Yr9, Yr11, Yr17, Yr18, Yr26, Yr27, Yr30, Yr32, YrA, YrSK, YrSP, YrSu, Yr(8,19), Yr(7,25), $\operatorname{Yr}(2, H V I I), \operatorname{Yr}(10, M o r), \operatorname{Yr}(7,22,23), \operatorname{Yr}(17,29)$

v75 Yr1, Yr2, Yr6, Yr8, Yr9, Yr11, Yr17, Yr25, Yr26, Yr27, Yr30, Yr32, YrA, YrSK, YrSP, YrSu, Yr(8,19), Yr(7,25), $\operatorname{Yr}(2, H V I I), \operatorname{Yr}(10, M o r), \operatorname{Yr}(17,29)$

v76 $Y r 1, Y r 2, Y r 6, \quad Y r 8, Y r 9, \quad Y r 11, Y r 18, Y r 26, Y r 30, Y r A, Y r(7,25), \operatorname{Yr}(17,29)$

v77 Yr1, Yr2, Yr6, Yr8, Yr9, Yr11, Yr17, Yr18, Yr25, Yr26, Yr30, Yr32, YrA, YrSK, YrSP, YrSu, Yr (8, 19), $\operatorname{Yr}(7,25)$, $\operatorname{Yr}(2, H V I I), \operatorname{Yr}(10, M o r), \operatorname{Yr}(7,22,23)$

v78 Yr1, Yr2, Yr7, Yr8, Yr17, Yr18, Yr25, Yr26, Yr32, YrA, YrSP, YrSu, Yr(8,19), Yr(7,25), Yr(2,HVII), Yr(10,Mor), $\operatorname{Yr}(17,29)$

v79 Yr1, Yr2, Yr8, Yr9, Yr17, Yr18, Yr25, Yr26, Yr30, YrA, YrSK, YrSP, YrSu, Yr(8,19), Yr(7,25), Yr(2,HVII), $\operatorname{Yr}(10, M o r), \operatorname{Yr}(7,22,23), \operatorname{Yr}(17,29)$

v80 Yr1, Yr2, Yr8, Yr9, Yr18, Yr25, Yr26, YrA, YrSP, YrSu, $\operatorname{Yr}(8,19), \operatorname{Yr}(7,25), \operatorname{Yr}(10, M o r), \operatorname{Yr}(17,29)$

v81 Yr1, Yr2, Yr8, Yr9, Yr11, Yr17, Yr18, Yr25, Yr26, Yr30, Yr32, YrA, YrSK, YrSP, YrSu, Yr(8,19), $\operatorname{Yr}(7,25)$, $\operatorname{Yr}(10, M o r), \operatorname{Yr}(17,29)$

v82 Yr1, Yr2, Yr9, Yr17, Yr25, Yr26, Yr30, YrSK, YrSP, YrSu, Yr(8,19), $\operatorname{Yr}(7,25), \operatorname{Yr}(2, H V I I), \operatorname{Yr}(10, M o r)$, $\operatorname{Yr}(7,22,23), \operatorname{Yr}(17,290.8$

v83 Yr1, Yr3, Yr8, Yr17, Yr18, Yr25, Yr26, Yr27, Yr32, YrSP, YrSu, Yr(8,19), Yr(2,HVII), Yr(10,Mor), Yr(17,29)

v84 Yr1, Yr8, Yr17, Yr18, Yr25, YrSP, $\operatorname{Yr}(7,25), \operatorname{Yr}(17,29)$

v85 Yr2, Yr3, Yr6, Yr7, Yr8, Yr9, Yr11, Yr17, Yr18, Yr25, Yr26, Yr30, Yr32 YrA, YrSK, YrSP, YrSu, Yr (8,19), $\operatorname{Yr}(7,25), \operatorname{Yr}(10, M o r), \operatorname{Yr}(17,29)$

v86 Yr2, Yr3, Yr7, Yr8, Yr9, Yr11, Yr17, Yr18, Yr25, Yr30, Yr32, YrA, YrSK, YrSP, YrSu, Yr(8,19), Yr(7,25), 0.8 YX $\operatorname{Yr}(10, M$ Mr $), \operatorname{Yr}(7,22,23), \operatorname{Yr}(17,29)$

$\uparrow$ Distribution item in the table without number means one isolate. Chuxiong (CX), Dali (DL), Honghe (HH), Kunming (KM), Lincang (LC), Lijiang (LJ), Nujiang (NJ), Qujing (QJ), Wenshan (WS), Yuxi (YX), SZhaotong (ZT), Sichuan (SC).

www.scienceasia.org 